\title{
What is it Like to be a Child? Childness in the Age of Neuroscience
}

\author{
Maria Nikolajeva ${ }^{1}$ \\ Published online: 5 February 2019 \\ (c) The Author(s) 2018
}

\begin{abstract}
This article considers alternatives to the established constructivist approaches to children's literature, exploring instead the potential of two relatively recent areas of inquiry, cognitive poetics and evolutionary literary criticism. The article questions the assumption, implied if not directly expressed by Peter Hollindale in Signs of Childness in Children's Books (1997), that adult writers have the prerogative to write about a child's experience because, since they once were children, a child's mind is accessible to them; that they can know what it is like to be a child. With reference to brain research, this position is untenable due to the cognitive gap between adult and child. While this binary has been strongly opposed in children's literature criticism, and while it is impossible and counterproductive to draw a clear-cut line between childhood and adulthood, Hollindale's concept of childness suggests a number of qualities that cognitive studies considers irretrievably lost when the brain is restructured during adolescence. The purpose and attraction of children's literature, therefore, lie in capturing and artistically representing these qualities.
\end{abstract}

Keywords Cognitive criticism $\cdot$ Evolutionary criticism $\cdot$ Neuroscience $\cdot$ Brain laterality $\cdot$ Memory $\cdot$ Childhood $\cdot$ Childness

\section{Introduction}

The title of this article alludes to the famous work that cognitive studies inevitably return to: "What is it like to be a bat?" by Thomas Nagel (1974). While it is possible to imagine, say, what it might be like to fly, to hang upside down and to use

\footnotetext{
Maria Nikolajeva is Professor of Education and Professorial Fellow of Homerton College at Cambridge University. In 2005 she received the International Brothers Grimm Award for a lifetime achievement in children's literature research.
}

Maria Nikolajeva

mn351@cam.ac.uk

1 Faculty of Education, University of Cambridge, 184 Hills Road, Cambridge CB2 8PQ, UK 
echolocation, a bat's subjective perception is so different from a human being's that it can never become a shared experience (see Blackmore, 2005, pp. 6-9). We cannot access the consciousness of a bat, or a cat, or a rat; we cannot even be sure that animals have consciousness, or whether some do while others do not. In 2012, a group of international scholars adopted The Cambridge Declaration on Consciousness, stating that all animals are sentient (Bekoff, 2012). While it is a decisive step for animal rights, from a philosophical viewpoint it is problematic. The most basic definition of consciousness includes the awareness of being sentient: does a bat know that it is a bat? Does a bat understand batness as a distinctive feature of selfhood? This philosophical dilemma of cognition highlights that it is by definition impossible to penetrate another living organism's mind, whether that is the mind of a bat, an elephant, a chimpanzee-or, as I argue here, a child. This impossibility has significant consequences for children's literature theory, because it forces us to consider alternatives to the established constructivist approaches to children's texts-initiated, among other scholars, by Karín Lesnik-Oberstein (1994) and strongly endorsed by various directions of critical theory.

In this article, I explore two relatively recent areas of inquiry, cognitive poetics and evolutionary literary criticism - the latter particularly hostile toward constructivism-claiming that any study of literature and art must take biological aspects of human existence into consideration. My exploration does not imply that I subscribe to either direction without reservation; however, I do find it valuable and desirable to approach children's literature from other angles than constructivism. Such approaches need not take us back to essentialism, that children's literature theory liberated itself from during the early 1990s. Rather, they question constructivism as the only possible epistemology, and hermeneutics as the only appropriate method. Thanks to cognitive science and evolutionary psychology, we know more today about minds and bodies than we did 100 years ago; it would be reductive not to investigate new possibilities offered by these disciplines, paying particular attention to embodiment as the foremost source of our engagement with the world, whether real or fictional. Some areas of children's literature research where such a focus on embodiment has already become prominent are ecocriticism (Harding et al., 2009; Cutter-Mackenzie et al., 2011; Curry, 2013) and disability studies (Dunn, 2015).

Paradoxically, it is useful to go back 20 years in order to gaze into the future. Rereading Peter Hollindale's Signs of Childness in Children's Books (1997), I noticed a detail that had previously escaped my attention: childness, for Hollindale, includes the child's awareness of being a child: "A child is someone who believes on good grounds that his or her condition of childhood is not yet over" (1997, p. 30). This self-awareness, as I see it, is key in Hollindale's concept of childness, as opposed to childhood predominantly defined by adults' awareness of a human being's condition of childhood. We have so far no reliable evidence that a bat knows that it is a bat, but do we have - and can we ever hope to have-evidence that children know that they are children? Hollindale seems to claim that we do, or at least, that we have strong reasons to assert that a child believes on good grounds that they are a child. And yet I feel that we cannot accept this stance without further consideration.

How can we, as adults, make assumptions about a child's consciousness? How can we know what it is like to be a child? A typical affirmative argument on this 
matter will probably go along the lines of: while none of us has experience of being a bat, we all have experience of having been a child. It can be argued that the unique quality and attraction of children's literature is its endeavour (not always successful) to convey a first-hand experience of childhood, ostensibly based on authors' childhood memories. This purportedly makes children's literature different from other kinds of fiction based on alterities: it has been questioned whether male authors are able (and entitled) to convey experiences of female characters, white authors black characters, or able-bodied authors disabled characters. Such an argument is ambiguous, since all fictional experiences, childhood included, are cultural and aesthetic constructions; and while first-hand experiences of age, gender, race, sexual orientation or disability may enhance artistic representation, they are not a decisive prerequisite.

Moreover, as contemporary cognitive narratology states, the main appeal of both writing and reading fiction is that it gives us access to other people's minds in a way that would be impossible in real life. For instance, Lisa Zunshine claims that the reward of reading fiction is "our awareness of our 'trying on' mental states potentially available to us but at a given moment differing from our own" (2006/2012, loc. 329-330; original emphasis). Suzanne Keen explains that fiction "provide[s] safe zones for readers' feeling empathy without experiencing a resultant demand on realworld action" (2008, loc. 350-351). As Blakey Vermeule simply puts it: "We need to know what other people are like" (2010, p. xii). In the case of children's literature, we may add the minds of animals, plants, toys, monsters, God, and Death. Thus cognitive literary theory places itself in direct opposition to what cognitive science today takes for granted: other people's minds are inaccessible, even though experimental psychology employing functional Magnetic Resonance Imaging (fMRI) is taking the first, cautious steps in making minds more transparent. Moreover, some philosophers, such as Yuval Harari, question the very existence of the mind as separate from the brain, and of consciousness as anything other than electrical and chemical processes (2016, pp. 123-154). While dualism goes all the way back to Descartes, contemporary brain research has significantly interrogated the traditional flesh/spirit divide (e.g. Damasio, 2006).

A paradox then. Science tells us that we can at best only access and assess our own consciousness, if there is even any such thing. Literary studies tell us that fiction is an adequate tool to at least contemplate how other minds work. Psychologists are starting to acknowledge the importance of fiction for their understanding of the workings of the mind (e.g. Oatley, 2011). In her insightful book Peter Pan and the Mind of J.M. Barrie, neuroscientist Rosalind Ridley states: "Literature and art have always been a primary source of psychological insight and writers and painters frequently bring to our attention the way things can be, so that we come to understand the world differently" (2016, p. 34). Literary studies, in turn, explore how cognitive functions, such as attention, memory, imagination, prediction, inference, and empathy are reflected in fiction and enable us to employ life-to-text and text-to-life strategies; that is, to bring our real-life experience to understanding fictional events and characters, and to transfer our understanding of fictional events and characters onto real-life events and relationships (Zunshine, 2006/2012; Keen, 2008; Vermeule, 2010; Hogan 2011; Hogan, 2012; Zunshine, 2015). Recent brain 
research demonstrates, albeit on a small scale and short term, that engaging with fiction enhances empathy and theory of mind; namely, our capacity to understand the thoughts and feelings of real and fictional people (e.g. Djikic et al., 2013; Kidd and Castano, 2013; Black and Barnes, 2015; Burke et al., 2016; Kidd et al., 2016). Psychologist Keith Oatley suggests that fiction also contributes to our social skills: "If fiction is the simulation of social worlds then, similar to people who improve their flying skills in a flight simulator, those who read fiction might improve their social skills" (2016, p. 619). Literary scholars seem to have finally received justification for their academic pursuit from sceptical colleagues within the natural and social sciences. We can claim that reading fiction is beneficial because it enhances our cognitive, emotional and social skills. Children's literature, then, might be a good implement for training children to become responsible and empathetic members of society.

Let us return to the question of what it is like to be a child. As Hollindale continually emphasises, one inherent feature of children's literature is the age imbalance between its creators and readers (even though there exists a marginal corpus of children's books written by children, or in collaboration with adults). From a cognitive perspective, I would word it as a cognitive-affective imbalance (Nikolajeva, 2014). Theoretically, this should not be a more complicated question than whether male writers can write persuasively about female characters, and so on. I am not questioning that adult writers can write persuasively about child characters' experiences: we know that it is not only possible, but indeed frequently successful to the extent that child and adult audiences alike consume books that ostensibly target young readers. And, I would guess, precisely because of, rather than despite, the childness (as opposed to childishness) of these books.

What I am questioning is the assumption, implied if not directly expressed by Hollindale, that writers can write about a child's experience because, since they once were children, a child's mind is accessible to them. Of course, while we cannot ask a bat how it perceives its batness, we can ask a child how they perceive their childness. Yet with our current understanding of the learning brain and its limited ability for self-reflection, we cannot with confidence rely on such evidence. My claim is that an adult writer knows hardly more about what it is like to be a child than what it is like to be a bat. This is because of the cognitive gap between adult and child; a gap that memory cannot bridge. I realise this is a provocative statement for anyone sympathetic to constructivism and to the suggestion that the child/adult binary should be replaced by a continuum (Gubar, 2011, 2016). While it is impossible, and indeed pointless, to insist on the existence of a clear boundary between childhood and adulthood, Hollindale's concept of childness can prove helpful in theorising the issue, while cognitive and developmental psychology offers us analytical tools to explore it.

My argument relies here on sources including Sarah-Jayne Blakemore and Uta Frith's The Learning Brain: Lessons for Education (2005), Usha Goswami's Cognitive Development: The Learning Brain (2007) and Michael Eysenck and Mark Keane's Cognitive Psychology: A Student's Handbook (2013). A human child is born with a big cranium that causes its mother considerable pain during childbirth, but that is necessary to contain a big brain (O'Shea, 2005, pp. 60-63). This brain is 
an extremely complex mechanism that, shortly after birth, must quickly fine-tune itself to external circumstances and take advantage of them to survive. For instance, a new-born baby's vocal cords and mouth resonator are equipped to replicate any sound of any human language. By the time the baby learns to pronounce their first real words in their ambient language(s), typically between 10 and 13 months, they lose the ability to distinguish between and thus reproduce sounds from other languages (Ambridge and Lieven, 2011, pp. 18-31). This happens because the brain is hungry: $20 \%$ of the energy from food and heat is used to support the brain, which includes maintaining networks between brain cells. Being an economical machine, the brain will not maintain the paths it decides it will not need. Because a young child's brain is extremely plastic, it is still possible in youth to recover lost paths; but the older one gets, the more effort it takes to learn a new language, and it becomes almost impossible to replicate sounds profoundly different from one's native tongue.

\section{"Signs of Childness" in the Developing Brain}

A learning brain keeps pruning trillions of connections between brain cells that a new-born baby may potentially need, but that may be unnecessary or unviable to maintain (Blakemore and Frith, 2005; O'Shea, 2005). We could speculate that if a young child is exposed to music, the brain will enhance the paths that support its perception. It will probably also support attention necessary to enjoy music, and will store emotional memories that make experience of music pleasurable. If the "musical" path is not used, they may be closed down. There is no scientific evidence of such processes yet, but it follows from what we know about brain development: the brain decides which experiences are salient, namely, worth storing for future recall, and which are irrelevant and can be dismissed. As imaginatively shown in the movie Inside Out (Docter and Del Carmen, 2015), the brain occasionally inspects its storage and disposes of experience that has not been recalled for a while.

During adolescence, the brain goes through major re-structuring (Byrne, 2003; Blakemore and Frith, 2005). I prefer to avoid technical language such as myelination; in short, the frequently used paths are cemented, while the less frequent are cut off. Because the cementing substance needs space, the pruning is substantial. Again, we may surmise that if paths for associating poetry, or fairy tales, or music with pleasure have not been maintained in childhood, they will be lost. If imagination has not been trained through reading, listening, watching, playing, it will not be reinforced as a valuable cerebral capacity. Imagination, at least in the restricted sense of the term as an ability for envisioning supernatural occurrences within the order of reality, is frequently highlighted as a key quality of childness. Yet even in the best of circumstances, a significant part of it will be sacrificed during adolescence in favour of other cognitive activities, such as prediction and decision-making, which are often recognised as tokens of maturity. This fact does not contradict the centrality of socialisation and acculturation, but complements it.

There are even more important "signs of childness" that may find explanation in brain processes. One of these has to do with brain laterality. Today's brain research dismisses earlier beliefs that each hemisphere has a clearly separate function; in fact, 
both hemispheres process verbal, visual, sensory and proprioceptive information, and both are essential for emotion as well as reason. In his ground-breaking study The Master and His Emissary: The Divided Brain and the Making of the Western World (2009) and the complementary essay The Divided Brain and the Search for Meaning (2012), philosopher and psychologist Iain McGilchrist explains the implications of the distribution of cognitive functions between cerebral hemispheres. My summary is inevitably simplified, and a neuroscientist would find such categorisation too primitive; but for the sake of my argument, the basic distribution of cerebral features is helpful: the right hemisphere is emotional, while the left is rational; the right is concrete, the left abstract; the right sees the whole in a context, while the left attends to details out of context; the right explores, the left categorises; and, perhaps most relevantly, the right hemisphere prioritises freshness, novelty, change, plurality and ambiguity. Both are equally important in our perception of the world, yet each perceives the world differently. In the follow-up essay, McGilchrist summarises the difference as follows: "while the left hemisphere's raison d'être is to narrow things down to certainty, the right hemisphere's is to open them up into possibility" (2012, loc. 151). I find the latter a perfect description of childness. McGilchrist's argument is that "[e]xplicitness kills, renders lifeless" (2012, loc. 180).

Recent brain research, McGilchrist details, shows that the hemispheres develop at a different pace and that in infancy and childhood, the right hemisphere dominates over the left. Further, the right hemisphere has firmer connectivity with the lower parts of the brain, often referred to as "ancient," that manage immediate sensory perceptions and affective responses, while the left hemisphere communicates better with the newer parts, which support analytical skills, abstract thinking and, partially, language. Psychologist and children's literature scholar Hugh Crago refers to the low parts of the brain as reptilian, the middle parts as mammalian, and the higher parts as human (2014, p. 7). While I find these labels, widely used in evolutionary psychology, problematic in what they imply of human superiority over animals, the categories are illuminating. A young child's brain is, thus, fundamentally more immediate and intuitive than an adult's, which would therefore be fundamentally more rational. If we cannot understand the mammalian consciousness of a bat, how can we assume that we understand the - to put it provocatively_ "reptile" consciousness of a child?

What are, then, the implications for adults' potential (mis)understanding of what it is like to be a child? If a child's right cerebral hemisphere is better developed, and if it is connected with the part of the brain that processes senses and emotions, it probably follows that children perceive the world differently to adults. Let us speculate what these differences might be, even though there is no conclusive evidence. Ostensibly, this hypothetical child shows more intuitive and less rational responses to external factors. A child connects to the environment and to other living organisms emotionally and immediately, with less rationalising, less categorizing of animals and objects, and with fewer attempts at making sense of them, than an adult; because the right hemisphere does not try to make sense, instead experiencing the world intuitively. "Making sense" has always been a priority in education (e.g. Bruner and Haste, 2011/1987; Matthews and Addleton, 1992); we assume that meaning-making, whether in real life or in engaging with fiction, is the ultimate goal 
of learning — but is that not a typically adult approach? Further, a child distinguishes less than an adult between the animate and the inanimate; children animate objects and anthropomorphise animals. A child experiences the world holistically, exploring more than categorising. A child relies more on sensory perception than on verbal information. A child does not shun novelty, ambiguity or strangeness, but believes in magic, wonder and the extraordinary. A child strives less than an adult to distinguish between fact and fiction, pretence and reality (Goswami, 2007, pp. 285-336), and enjoys the world as it is. As we grow up, we gradually lose these qualities because the left hemisphere catches up and takes over. This process is evolutionarily determined. It seems, then, that as adults, we will never be able to perceive the world as we did when we were children.

Furthermore, the brain retains no memory of such perception, as I will explain; as adults, we lose "childness," the quality of being a child. In his recent book Enlightenment Now: The Case for Reason, Science, Humanism, and Progress (2018), cognitive psychologist Steven Pinker argues that evolution, alongside entropy, is the worst adversary of humanity and that human activities covered broadly by the concept of culture counterbalance the evolutionary purpose focused exclusively on reproduction. To do this, we need the skills supported by the left hemisphere: distinguishing between the real and the imaginary; thinking in abstract categories; making predictions and inferences; balancing egoism and altruism. Playfulness needs to be at least partially sacrificed to make room for reason.

Two skills are crucial in the transition from childness to, we could say, "adultness": theory of mind and empathy. Theory of mind is the capacity to understand other people's thoughts, opinions, beliefs and intentions independently of one's own. In neurotypical children it emerges around the age of four (Doherty, 2009). Prior to that, and occasionally after that, a child is self-centred, or as J.M. Barrie puts it, "gay and innocent and heartless" (1951/1911, p. 192). Barrie's view is of course marked by typical Victorian nostalgia, but his observation is not entirely unfounded, and it has an evolutionary reason: in order to survive, children need to be fully focused on their own needs, which include food and protection. A child has limited capacity for causality, prediction, problem-solving and decision-making; a child will always favour short-term goals and immediate gratification over long-term outcomes (Goswami, 2004, pp. 182-219, 294-333; Goswami, 2007, pp. 377-398; Eysenck and Keane, 2013, pp. 457-568). From an adult perspective, these traits may be viewed as flaws, or perhaps as another example of nostalgic cuteness; but they are indelible components of childness. Even during adolescence, or maybe particularly during adolescence, a young person is likely to put their own interests before anyone else's.

Empathy is the capacity to understand other people's emotions independently of one's own. Suzanne Keen defines empathy as "a vicarious, spontaneous sharing of affect [that] can be provoked by witnessing another's emotional state, by hearing about another's condition, or even by reading" (2008, loc. 353; emphasis added). Empathy is closely related to theory of mind, but is more complex and is not fully developed until late adolescence (e.g. Rosenblum and Lewis, 2003). This is the physiological basis for the frequent descriptions of adolescence as a stage of emotional turmoil, even though those descriptions are culturally, socially and historically variable. A very young child can recognise the five basic emotions: joy, sadness, 
anger, fear and disgust, which are anthropomorphised in Inside Out. In adolescence, however, a wide range of social, or higher-cognitive emotions need to be mastered: love, hatred, envy, jealousy, pride, guilt (Oatley, 1992; Evans, 2001; Lewis et al., 2008). Unlike basic emotions, social emotions involve more than one individual. Here the natural aspects of childness come into conflict with societal demands. It is beneficial for a child to be selfish, but at the same time it is essential that children learn to understand and respect other individuals as well as societal rules and practices. Most neurotypical adults have mastered empathy and learned to balance their own emotional investments with those of other people, groups and societies. This process has resulted in a restructuring of the brain that now favours altruism over egoism. The adult brain has "forgotten" what it is like to be a child and to put one's own needs before everybody else's.

\section{Childness Lost}

I will discuss a few more "signs of childness" that are transformed or lost as we age and mature cognitively and emotionally. In doing so I will try to avoid the usual practice, of which I too have been guilty, of presenting certain cognitive traits as limited or absent. Instead, I will view them as valuable qualities inherent to childness, impossible to retain and experience in adulthood. Childness, as Hollindale defines it, is not a lack of adult skills and qualities; it is a set of qualities that we as adults have no labels for, since we are used to measuring and evaluating things from our own perspective, by default.

A child's sense of space and place, direction and dimensionality, scale and proportion, is different from an adult's (Matthews and Addleton, 1992). This is not due exclusively to the fact that a child is physically smaller than an adult, but also that these aspects of perception are primarily performed by the left cerebral hemisphere. As our brains are restructured during adolescence, we "forget" how incredibly large the distance between two places was and how long it felt to get from place to place. We forget how we tried to squeeze a very large doll into a very small bed. We forget how it felt not to be able to understand the difference between right and left. A book full of childness may remind us: "Pooh looked at his two paws. He knew that one of them was the right, and he knew that when you had decided which of them was the right, then the other one was the left, but he never could remember how to begin" (Milne, 1965b/1928, p. 119). The left hemisphere has the abstract knowledge, but the right hemisphere cannot apply it.

A child's sense of time is different from that of an adult (Piaget, 1969). A book full of childness says: "Once upon a time, a very long time ago now, about last Friday..." (Milne 1965a/1926, p. 2). For a child, waiting for the next birthday or for Christmas is eternal: to paraphrase C.S. Lewis (1950/1959, p. 25), always winter, and never Christmas. For a child, a person of twenty is ancient. Any span of time beyond a child's age is inconceivable. Being left alone for just a few minutes is equal to being abandoned; returning after years, like Peter Pan, to find your playmate grown up, is incomprehensible. The past is irrelevant, the future is non-existent. 
Children's literature frequently conveys this singularity of perception by using the present narrative tense, perhaps in part because, as McGilchrist expresses it, "The right hemisphere's world is present" (2012, loc. 211).

Our daily rhythm is determined by the levels of various chemicals released by the brain into our bodies that regulate our energy and tell us when we need to rest and sleep. This biopsychological fact is cemented in culture by routines and habits necessary for societies to function. When young children do not want to go to bed, it is because their brains have not yet learned to follow the daily rhythm of light and darkness. A child simply falls asleep when they are tired and wakes up when they are rested, much to parents' irritation. For an adult, the chemical process works on a 24-hour basis, enhanced by socially constructed patterns of daily life. The rhythm is disturbed when we travel across several time zones; we call it jetlag. Because of hormonal disruptions, an adolescent's daily rhythm works on a 25-hour basis, which means that every day a teenager's chemical balance is shifted by an hour against the actual clock. Teenagers live with perpetual jetlag (Bainbridge, 2009, pp. 114-118). In neurotypical adults, the daily rhythm is regulated both biologically and socially. We forget what it was like to be out of sync. We accuse teenagers of being lazy.

A child's understanding of causality and entropy differs from an adult's. It is not at all surprising for a child that time can run backwards, or that broken objects can become whole, or that dead people can become alive. Children may have difficulties understanding the consequences of their own and other people's actions. We can say that they are irresponsible, but often, in the West at least, children's carefreeness has been perceived romantically as unlimited freedom. They have been viewed as able to fully practise their free will, unrestricted by adult systems of beliefs and values, unencumbered by questions about what is right and wrong. Yet, in other respects, adults have sought to curtail that apparent freedom, labelling it undesirable, and trying to socialise children and make them abandon the habit of judging their own and other people's actions from a self-centred position. Obviously, the nostalgic view of childhood freedom is by necessity exclusive of those children who do not have the privilege to be carefree; in societies where children work, for instance, there is no social expectation that they should display that freedom.

We can say that a child has limited real-life experience, including the experience of time and space, social structures and interpersonal relationships (Goswami, 2004, pp. 2-73, 108-145; Goswami, 2007, pp. 213-238; Bruner and Haste, 1987). But in exchange, for a child everything is new and unfamiliar; the right hemisphere favours novelty, and everything is "for the very first time." Can we as adults really know what it is like to see or do something ordinary for the first time? Nothing is really ordinary for a child.

We can say that a child has a less developed attention span, which is not merely an important cognitive skill, but is also necessary for successful social interaction (Eysenck and Keane, 2013, pp. 153-202). Yet lack of attention can also be described as insatiable curiosity. A child's memory is less developed to process, store, retrieve and reconnect lived and mediated experience (Goswami, 2004, pp. 250-293; Goswami, 2007, pp. 347-376; Eysenck and Keane, 2013, pp. 203-326). The narrator of Peter Pan and Wendy, therefore, is not wrong to label the "happy forgetfulness" (Barrie, 1951/1911, p. 78) as a quality of childness; the values and beliefs children's 
literature has associated with childhood are not devoid of grounding in biological fact. A child has not yet developed a clear sense of self: children are solipsistic, and their capacity for self-reflection is limited (Dusek and McIntyre, 2003). Yet an underdeveloped sense of self implies a range of unrealised potentials, just as the unsettled daemons of Philip Pullman's His Dark Materials play with many possible identities. As we grow up, our daemons become fixed, and we lose the potential to become something else. The incompleteness, in the Bakhtinian sense (Bakhtin, 1981), the mouldability, corresponding to the plasticity of the brain, is what makes a child a child, and what we as adults can imagine, but never take part in.

What becomes obvious through brief reflections on these biological, physiological and neurological observations is that a child's experience of the perceptible world, as well as of their own interiority, is so profoundly detached from that of an adult that it is hardly feasible to claim that an adult has first-hand knowledge of this experience. And yet, just as many mainstream writers have successfully managed to portray the consciousness of various outgroups, children's literature has managed to capture some of the enigmas of a child's mind. The achievement is all the more extraordinary; and instead of saying, as constructivists might, that children's literature moulds or manipulates childhood, we could say that it is quite remarkable that some adults have in fact been able to spot fundamental aspects of children's perceptions, and to render them through language in their works.

\section{The (Im)Persistence of Memory}

What about the treasure trove of childhood memories? Unfortunately, there is not much scientific evidence for it either. In her work on re-memorying, Alison Waller (2017) claims that it is possible for adults to reconstruct childhood reading experience. However, while this methodology is arguably applicable to reading, where one can check recollections of a text against the text itself, there is no way of checking the accuracy of memory against actual events, and still less the accuracy of emotional involvement with these events. Contemporary memory research, building on neuroscience, leaves no doubt about the reliability of episodic memory, that is, long-term memory that preserves our real-life experience, unlike semantic memory that deals with factual knowledge (e.g. Schacter, 1997; Baddeley, 1999; Tulving and Craik, 1999; Foster, 2009). Memory, as a cognitive function based on chemical and electrical processes in the brain, does not render an event or an emotion as it was experienced, but rather as it was encoded and stored when transferred from shortterm to long-term memory (O'Shea, 2005, pp. 84-101). Unlike semantic memories that can be verified, episodic memories are "personal, highly selective, idiosyncratic, and probably false" (p. 88). The rational left cerebral hemisphere, trying to make sense of the emotionally charged experience accumulated by the right hemisphere, tries to sort it into pre-determined categories, to make it coherent, to transform it into a properly structured, linear narrative rather than a non-narrative, non-linear, multisensory whole. That is, even before a memory of a mental state is stored, it is already altered by the left hemisphere's processing. In his insightful book Homo Deus: A Brief History of Tomorrow (2016), macro-historian and philosopher Yuval 
Harari refers to this split perception as the impenetrable barrier between the experiencing and the narrating selves, in which the latter, the left hemisphere, is at best a deluded fabricator, at worst, a deliberate liar (pp. 342-348). Through fMRI, neuroscientists have identified parts of the brain where false memories are stored ( $\mathrm{O}$ 'Shea, 2005 , p. 27). Thus, a memory is never authentic, but always distorted, reflecting individual subjective perception and external circumstances, which can be easily proved if two people's sets of memories of the same event are compared.

Against the background of memory research, the romanticised view of so-called authentic childhood memories, whether idyllic or traumatic, becomes highly contestable. They are not genuine recollections, but confabulations. The concept of confabulation implies that an author who would claim to write from memory honestly believes that the memory is accurate. The author's position, then, corresponds to the position of the rational left hemisphere that endeavours to organise the chaotic empirical experience into a logical narrative: "[i]t is demonstrably self-deceiving, and confabulates-makes up a story, when it cannot understand something, and tells it with conviction" (McGilchrist, 2012, loc. 384). To maintain that children's literature utilises a memory-based child perspective is an illusion. Authors may possibly be able to recall superficial events (episodic memory, unreliable in itself), but not the emotional states evoked by these (Hogan, 2003, pp. 159-162). To suggest that the success of children's literature depends on authors' acute memories of their own childhood is cognitively untenable. These "memories" are just as much a construction as any other fiction, even if they are supported by diaries or other documents; and they are most likely based on a nostalgic view of childhood, on "self-induced emotional states of longing for the past" (Nalbantian, 2003, p. 41). In other words, authors who make that kind of allegation are trying to reach for an unreachable childness.

The attraction of returning to childhood experience is understandable. Cognitive critic Patrick Hogan refers to memory-based fiction as "recuperative creativity" (2003, p. 78); that is, attempts to recover what was lost in the left hemisphere's systematisation of experience, instead capturing the right hemisphere's spontaneous response. This attitude echoes, albeit in a more positive tone, the definition of children's literature as self-therapy for frustrated adults, as suggested by Jacqueline Rose (1984). Yet, as I have repeatedly pointed out, cognitive narratologists' arguments do not take young readers' cognitive asymmetry into consideration (Nikolajeva, 2014). For Hogan and other scholars, "recuperative creativity" implies that the reader, adult by default, is attuned to the author's endeavours because these reflect a reader's own attempts to access some sense of their lost childness. For child readers, however, recuperation is irrelevant. Their childness is there, and therefore their pursuit is to recognise and connect with the childness of the fictional child or, more broadly, the childness of the book.

The dilemma of children's literature thus becomes twofold. First, we have an adult writer attempting to create a fictional alien, that is, childly mind. Second, we have an ostensibly childly reader attempting to understand, or model, as a cognitive critic would call the process (Stockwell and Mahlberg, 2015), a fictional childly mind created by an alien, un-childly mind. The former case, I would argue, is less complicated than children's literature scholars have made it seem so far (e.g. 
Nodelman, 2008; Nikolajeva, 2010). The childness of a fictional child is not radically different from the batness of a fictional bat-for instance, Randall Jarrell's The Bat-Poet (1967) — or the otherness of any fictional character. Moreover, the childness of a child in children's fiction is not radically different from the childness of a child in fiction targeting adult audiences, because it is based on a set of qualities, as Hollindale defines childness, of being a child, including awareness of being a child. Both are equally unknowable for the writer, as I have argued. The latter case, however (that is, an actual child mind-modelling a fictional child created by an adult) is indeed what sets encounters with children's literature apart from all other kinds of reading experiences.

The fictional child that readers encounter in any kind of books is created by adult writers' imaginations and unreliable memories, which can also be memories by proxy-for instance, through factual or fictional stories. For an adult reader, the experience of mind-modelling a fictional child, whether the book targets a young or adult audience, is modelling an alien mind, a childly mind. For a child reader, modelling a fictional childly mind may or may not be a recognisable experience. Since it is an experience mediated through the adult writer, the success of such mind-modelling does not depend on the parity of the reader and the character. For a childly reader, too, the mind of the fictional child is just as familiar or unfamiliar as the mind of a bat or, indeed, an adult. If the writer uses imagination to create childness, the childly reader uses imagination to read childness. The childness of the child reader does not necessarily make them better equipped to engage with the childness of the character. Yet I am prepared to admit that the child reader's awareness of being a child can be beneficial for connecting with the child character, or rather a childly character, since the character does not have to be a child: it can be a bat. Or a cat. Or a rat, as in Philip Pullman's I Was a Rat! (1999).

However, the childness of the book, as Hollindale defines it, is radically different in a text with a projected young audience or even dual or multiple audiences. Hollindale offers a wide repertoire of signs of childness in a children's book, most of which have, since the study was published, been thoroughly investigated (e.g. Bradford, 2007; Waller, 2010; Carroll, 2012a, b; Sainsbury, 2013; Trites, 2014; Dunn, 2015; Jaques, 2015). I am not suggesting that children's literature scholarship has accomplished Hollindale's agenda, not least because the complexity of childhood as investigated by related areas, such as psychology, sociology, disability studies or critical race theory, brings in new aspects to the childness of children's literature that need to be explored. Yet we are closer today to an understanding of the childness of the book than we were 20 years ago. I will therefore not dwell further on Hollindale's categories, but being a book person rather a child person, I would emphasise that a genuinely childly text has the potential to be understood and enjoyed by a child reader; a potential that may or may not be realised by each reader. It is therefore difficult, and possibly pointless, to generalise, claiming that this text is more childly than that one, just as it is pointless to claim that this child is more childly than that child.

What is the enigmatic appeal of childness that so many critics have been trying to explain? I will try to address this question from several viewpoints reflecting today's state of the art in children's literature scholarship. First, childness is an aesthetic 
challenge, just as any other alterity is an aesthetic challenge, that needs imagination, keen observation, and empathy. Second, as Clémentine Beauvais claims (2015), childness is a political project, an adult author's investment in the future. Third, from an evolutionary perspective (e.g. Boyd, 2010; Carroll, 2011, 2012a, b; Gottschall, 2012), childness is an imagined order supported by evolution for the survival of humanity. Imagined orders include culture, arts, science, religion, ethics, property, law, social hierarchies, interpersonal relationships, social justice and education: activities that do not directly contribute to evolution, and yet obviously prioritised as beneficial for survival.

If childness has endured, we can infer that it has been valuable from an evolutionary viewpoint. Childness, the set of qualities of being a child, is, then, evolutionarily conditioned, and also expanded upon by society and culture. Adult writers invest in childness because maintaining childness in children is a good survival strategy. Ascribing a concept as complex as childness to evolution may seem reductive, but taken together with artistic challenge, this explanation brings us closer to understanding some of the unique power and necessity of children's literature.

Open Access This article is distributed under the terms of the Creative Commons Attribution 4.0 International License (http://creativecommons.org/licenses/by/4.0/), which permits unrestricted use, distribution, and reproduction in any medium, provided you give appropriate credit to the original author(s) and the source, provide a link to the Creative Commons license, and indicate if changes were made.

\section{References}

Ambridge, Ben, and Lieven, Elena. (2011). Child Language Acquisition: Contrasting Theoretical Approaches. Cambridge: Cambridge University Press.

Baddeley, Alan. (1999). Essentials of Human Memory. New York: Psychology Press.

Bainbridge, David. (2009). Teenagers: A Natural History. London: Portobello.

Bakhtin, Mikhail. (1981). The Dialogic Imagination. Trans. Caryl Emerson and Michael Holquist. Austin, TX: University of Texas Press.

Barrie, James M. (1951/1911). Peter Pan and Wendy. London: Hodder \& Stoughton.

Beauvais, Clémentine. (2015). The Mighty Child: Time and Power in Children's Literature. Amsterdam: John Benjamins.

Bekoff, Marc. (2012). Animals Are Conscious and Should Be Treated as Such. New Scientist, 215(2883), 24-25.

Black, Jessica, and Barnes, Jennifer L. (2015). Fiction and Social Cognition: The Effect of Viewing Award-Winning Television Dramas on Theory of Mind. Psychology of Aesthetics, Creativity, and the Arts, 9(4), 423-429.

Blackmore, Susan. (2005). Consciousness: A Very Short Introduction. Oxford: Oxford University Press.

Blakemore, Sarah-Jayne, and Frith, Uta. (2005). The Learning Brain: Lessons for Education. London: Wiley Blackwell.

Boyd, Brian. (2010). On the Origin of Stories: Evolution, Cognition and Fiction. Cambridge, MA: Harvard University Press.

Bradford, Clare. (2007). Unsettling Narratives: Postcolonial Readings of Children's Literature. Ontario: Wilfrid Laurier University Press.

Bruner, Jerome and Haste, Helen (Eds). (1987/2011). Making Sense: The Child's Construction of the World. London: Routledge.

Burke, Michael, Kuzmičová, Anežka, Mangen, Anne, and Schilhab, Theresa. (2016). Empathy at the Confluence of Neuroscience and Empirical Literary Studies. Scientific Study of Literature, 6(1), $6-41$. 
Byrne, James P. (2003). Cognitive Development during Adolescence. In Gerald Adams and Michael Berzonsky (Eds.), Blackwell Handbook of Adolescence (pp. 227-246). London: Blackwell.

Carroll, Jane. (2012a). Landscape in Children's Literature. London: Routledge.

Carroll, Joseph. (2011). Reading Human Nature: Literary Darwinism in Theory and Practice. Albany, NY: State University of New York Press.

Carroll, Joseph. (2012b). Literary Darwinism: Evolution, Human Nature, and Literature. New York: Routledge.

Crago, Hugh. (2014). Entranced by Story: Brain, Tale and Teller, from Infancy to Old Age. New York: Routledge.

Curry, Alice. (2013). Environmental Crisis in Young Adult Fiction: A Poetics of Earth. New York: Routledge.

Cutter-Mackenzie, Amy, Payne, Philip G., and Reid, Alan (Eds.). (2011). Experiencing Environment and Place through Children's Literature. New York: Routledge.

Damasio, Antonio. (2006). Descartes' Error: Emotion, Reason and the Human Brain. London: Vintage.

Djikic, Maja, Oatley, Keith, and Moldoveanu, Mihnea C. (2013). Reading Other Minds: Effects of Literature on Empathy. Scientific Study of Literature, 3(1), 28-47.

Docter, Peter, and Ronnie (Directors), Del Carmen. (2015). Inside Out. Emeryville, CA: Pixar.

Doherty, Martin J. (2009). Theory of Mind: How Children Understand Others' Thoughts and Feelings. Hove: Psychology Press.

Dunn, Patricia A. (2015). Disabling Characters: Representations of Disability in Young Adult Literature. New York: Peter Lang.

Dusek, Jerome B., and McIntyre, Julie Guay. (2003). Self-Concept and Self-Esteem. In Gerald Adams and Michael Berzonsky (Eds.), Blackwell Handbook of Adolescence (pp. 290-310). London: Blackwell.

Evans, Dylan. (2001). Emotions: A Very Short Introduction. Oxford: Oxford University Press.

Eysenck, Michael, and Keane, Mark. (2013). Cognitive Psychology: A Student's Handbook, 6th ed. New York: Psychology Press.

Foster, Jonathan K. (2009). Memory: A Very Short Introduction. Oxford: Oxford University Press.

Goswami, Usha (Ed). (2004). Blackwell Handbook of Childhood Cognitive Development. London: Wiley-Blackwell.

Goswami, Usha. (2007). Cognitive Development: The Learning Brain. New York: Psychology Press.

Gottschall, Jonathan. (2012). The Storytelling Animal: How Stories Make Us Human. New York: Houghton Mifflin Harcourt.

Gubar, Marah. (2011). On Not Defining Children's Literature. PMLA, 126(1), 209-216.

Gubar, Marah. (2016). The Hermeneutics of Recuperation: What a Kinship-model Approach to Children's Agency Could Do for Children's Literature and Childhood Studies. Jeunesse: Young People, Texts, Cultures, 8(1), 291-310.

Harari, Yuval Noah. (2016). Homo Deus: A Brief History of Tomorrow. London: Harvill Secker.

Harding, Jennifer, Thiel, Elizabeth, and Waller, Alison (Eds.). (2009). Deep into Nature: Ecology, Environment and Children's Literature. Lichfield: Pied Piper.

Hogan, Patrick Colm. (2003). Cognitive Science, Literature and the Arts: A Guide for Humanists. New York: Routledge.

Hogan, Patrick Colm. (2011). What Literature Teaches Us about Emotions. Cambridge: Cambridge University Press.

Hogan, Patrick Colm. (2012). Affective Narratology: The Emotional Structure of Stories. Lincoln, NE: University of Nebraska Press.

Hollindale, Peter. (1997). Signs of Childness in Children's Books. Stroud: Thimble Press.

Jaques, Zoe. (2015). Children's Literature and the Posthuman: Animal, Environment, Cyborg. London: Routledge.

Jarrell, Randall. (1967). The Bat-Poet. New York: Atheneum.

Keen, Suzanne. (2008). Empathy and the Novel. Oxford: Oxford University Press.

Kidd, David Comer, and Castano, Emanuele. (2013). Reading Literary Fiction Improves Theory of Mind. Science, 342(6156), 377-380.

Kidd, David Comer, Ongis, Martino, and Castano, Emanuele. (2016). On Literary Fiction and its Effects on Theory of Mind. Scientific Study of Literature, 6(1), 42-58.

Lesnik-Oberstein, Karín. (1994). Children's Literature, Criticism and the Fictional Child. Oxford: Clarendon.

Lewis, C. S. (1950/1959). The Lion, the Witch and the Wardrobe. Harmondsworth: Penguin. 
Lewis, Michael, Haviland-Jones, Jeannette, and Feldman Barrett, Lisa (Eds). (2008). Handbook of Emotions. New York: Guilford Press.

Matthews, M.H., and Addleton, Shirley. (1992). Making Sense of Place: Children's Understanding of Large Scale Environments. Hemel Hempstead: Harvester.

McGilchrist, Iain. (2009). The Master and His Emissary: The Divided Brain and the Making of the Western World. New Haven, CT: Yale University Press.

McGilchrist, Iain. (2012). The Divided Brain and the Search for Meaning. New Haven, CT: Yale University Press.

Milne, A.A. (1965a/1926). Winnie-the-Pooh. London: Methuen.

Milne, A.A. (1965b/1928). The House at Pooh Corner. London: Methuen.

Nagel, Thomas. (1974). What Is It Like to Be a Bat? The Philosophical Review, 83(4), 435-450.

Nalbantian, Suzanne. (2003). Memory in Literature from Rousseau to Neuroscience. Basingstoke: Palgrave.

Nikolajeva, Maria. (2010). Power, Voice and Subjectivity in Literature for Young Readers. New York: Routledge.

Nikolajeva, Maria. (2014). Reading for Learning: Cognitive Approaches to Children's Literature. Amsterdam: John Benjamins.

Nodelman, Perry. (2008). The Hidden Adult: Defining Children's Literature. Baltimore, MD: Johns Hopkins University Press.

O'Shea, Michael. (2005). The Brain: A Very Short Introduction. Oxford: Oxford University Press.

Oatley, Keith. (1992). Best Laid Schemes: The Psychology of Emotions. Cambridge: Cambridge University Press.

Oatley, Keith. (2011). Such Stuff as Dreams: The Psychology of Fiction. London: Wiley Blackwell.

Oatley, Keith. (2016). Fiction: Simulation of Social Worlds. Trends in Cognitive Sciences, 20(8), $618-628$.

Piaget, Jean. (1969). The Child's Conception of Time. London: Routledge and Kegan Paul.

Pinker, Steven. (2018). Enlightenment Now: The Case for Reason, Science, Humanism, and Progress. London: Penguin.

Pullman, Philip. (1999). I Was a Rat! or The Scarlet Slippers. London: Doubleday.

Ridley, Rosalind. (2016). Peter Pan and the Mind of J. M. Barrie. Newcastle: Cambridge Scholars Press.

Rose, Jacqueline. (1984). The Case of Peter Pan, or The Impossibility of Children's Fiction. London: Macmillan.

Rosenblum, Gianine, and Lewis, Michael. (2003). Emotional Development in Adolescence. In Gerald Adams and Michael Berzonsky (Eds.), Blackwell Handbook of Adolescence (pp. 269-289). London: Blackwell.

Sainsbury, Lisa. (2013). Ethics in British Children's Literature: Unexamined Life. London: Bloomsbury.

Schacter, Daniel L. (1997). Searching for Memory: The Brain, the Mind, and the Past. New York: Basic Books.

Stockwell, Peter, and Mahlberg, Michaela. (2015). Mind-modelling with Corpus Stylistics in David Copperfield. Language and Literature, 24(2), 129-147.

Trites, Roberta Seelinger. (2014). Literary Conceptualizations of Growth: Metaphors and Cognition in Adolescent Literature. Amsterdam: John Benjamins.

Tulving, Endel, and Craik, Fergus (Eds.). (1999). The Oxford Handbook of Memory. Oxford: Oxford University Press.

Vermeule, Blakey. (2010). Why Do We Care about Literary Characters? Baltimore, MD: Johns Hopkins University Press.

Waller, Alison. (2010). Constructing Adolescence in Fantastic Realism. London: Routledge.

Waller, Alison. (2017). Re-memorying: A New Phenomenological Methodology in Children's Literature Studies. In Clémentine Beauvais and Maria Nikolajeva (Eds.), Edinburgh Companion to Children's Literature (pp. 136-149). Edinburgh: Edinburgh University Press.

Zunshine, Lisa. (2006/2012). Why We Read Fiction: Theory of Mind and the Novel. Columbus, OH: The Ohio State University Press.

Zunshine, Lisa (Ed.). (2015). The Oxford Handbook of Cognitive Literary Studies. Oxford: Oxford University Press. 